\title{
Detection of Heavy Metals in Vegetables Cultivated In Different Locations in Chittagong, Bangladesh
}

\author{
$*$ Rashida Parvin ${ }^{1}, *$ Afroza Sultana ${ }^{2}$, Md. Ashrafuzzaman Zahid $^{3}$ \\ ${ }^{1,2}$ Faculty of food Science \& Technology, Chittagong Veterinary \& Animal Sciences University, Khulshi-4225, \\ Chittagong, Bangladesh. \\ ${ }^{3}$ Dept. of Nutrition \& Food Technology, Jessore Science and Technology University (JSTU), Jessore-7408, \\ Bangladesh.
}

\begin{abstract}
Five types of vegetables (Green arum leaves, jute leaves, water spinach, bottle gourd, wax gourd and sweet gourd) were collected from four different industrial areas (Nasirabad, Agrabad, Vatiary and Chalkbazar) in Chittagong, Bangladesh and analyzed three types of heavy metals viz. $\mathrm{Cu}, \mathrm{Pb}$ and $\mathrm{Cr}$ by Atomic Absorption Spectrophotometer. The results showed the concentration of $\mathrm{Cu}$ was within permissible limit for all samples. $\mathrm{Cu}$ concentration varied 1.23 to $25.04 \mathrm{mg} / \mathrm{kg}$. Cr concentration exceeds the normal range for leafy vegetables as $4.25 \mathrm{mg} / \mathrm{kg}$ for jute leaves (Chalkbazar), $3.21 \mathrm{mg} / \mathrm{kg}$ for water spinach (Chalkbazar), $2.96 \mathrm{mg} / \mathrm{kg}$ for water spinach (Nasirabad) than non leafy vegetables. Samples from vatiary had the Cr concentration within safe limit. The concentration of $P d$ found in leafy vegetables was too much high. The range of $P b$ found in all samples was $0.08 \mathrm{mg} / \mathrm{kg}$ (sweet gourd) to $2.99 \mathrm{mg} / \mathrm{kg}$ (jute leaves) where the guideline concentration of WHO was 30, 2.3 and $0.3 \mathrm{mg} / \mathrm{kg}$ for $\mathrm{Cu}, \mathrm{Cr}$ and $\mathrm{Pb}$ respectively. In respect to $\mathrm{Pb}$ concentration, the order of locations according to heavy metal was Nasirabad > Agrabad>Chalkbazar> Vatiary. Vegetables from industrial areas were contaminated with heavy metals viz. Cr and $\mathrm{Pb}$ which would be health hazardous for consumer.
\end{abstract}

Keywords: Bottle gourd, Green arum leaves, Jute leaves, Water spinach, Wax gourd and Sweet gourd.

\section{Introduction}

Security of environment is the most crucial question today. Explosive population growth, quick evolution in science and technology, massive industrialization and use of various chemicals in agriculture and most importantly, human activities are the factors threatening of life [1]. Vegetables are the essential lifesupporting materials for human beings and animals because vegetables contain fundamental nutrients as proteins, vitamin, iron, calcium and other nutrients [2]. Rapidly increasing urbanization and emission of heavy metal contaminated fumes from the industries and vehicles have contribution to agriculture soils and consequently in food chain by deposited on the vegetable surfaces during their production, transport and marketing. Application of wastewater to irrigate agricultural lands is one of familiar practice in suburban and industrial areas in many parts of the world [3]. According to chemical properties, heavy metals are elements that reveal metallic properties and are defined based on density, atomic number or atomic weight, chemical properties or toxicity [4]. Recent reports indicated that heavy metals take driver's seat among the chief contaminants of leafy vegetables. Dietary ingestion of heavy metals infected vegetables may pose serious hazard to human health. Plants can receive these metals from soil by their roots, transport them upwards to their shoots, and finally collect them inside their tissues, although there are large variations among different plant species in terms of metal gathering capacity [5]. It has been reported that almost half of the means of intake of lead, copper and chromium through food is due to plant origin (fruit, vegetables and cereals) and it sometimes in more than permissible limits within urban areas [6]. Conversely, nutritional value and consumer reception must be taken into contemplation when vegetables are being considered as food, because vegetables can contain both essential and nonessential elements over a wide range of concentrations [7]. Therefore, it is essential to determine elemental contents of food items and to estimate their daily dietary intake [8]. Copper and lead are essential micronutrients obtained from vegetables [9] but at high levels they originate oxidative stress through redox reactions in young children and it causes mental retardation while some oxidative forms of chromium $(\mathrm{Cr}$ VI) are carcinogenic. As alertness of the risk of heavy metal pollution in food chain increases national and international regulations on food quality have lowered the maximum acceptable levels of toxic heavy metals in food items [10]. The objectives of these regulations are to save human health and natural resources from toxicity of these heavy metals.

Monitoring and assessment of heavy metal concentrations in the vegetables from the market sites have been carried out in some developed and developing countries, but limited published data are available on heavy metal concentrations in the vegetables from the market sites in Bangladesh. Considering the importance of heavy metals and consumption of vegetables, this inquiry was carried out. 
So, our study aim was to find out the occurrence and concentrations of some heavy metals such as Chromium $(\mathrm{Cr})$, Copper $(\mathrm{Cu})$ and Lead $(\mathrm{Pb})$ from some locally available vegetable species that are frequently consumed by the local population of Chittagong city, Bangladesh.

Completing this study, the findings will help people to alert about consuming vegetables which are cultivated in the industrial areas.

\section{Methods}

Five leafy and non leafy vegetable (Table 1) samples were collected from four different industrial areas (Nasirabad, Agrabad, Chalkbazar and Vatiary) of Chittagong, Bangladesh and washed thoroughly with tap water followed by distilled water to remove adsorbed elements. Samples were cut into small pieces; air dried for 2 days and kept in hot air oven at $100^{\circ} \mathrm{C} \pm 1^{\circ} \mathrm{C}$ for $4 \mathrm{hrs}$. After drying, the samples were grounded to powder [11]. A solution of $\mathrm{H}_{2} \mathrm{SO}_{4}(65 \%), \mathrm{HClO}_{4}(65 \%)$ and $\mathrm{HNO}_{3}(70 \%)$ with ratio of 1:1:5 was used for digestion of the samples. One $\mathrm{g}$ of dry powder of each sample was digested using $15 \mathrm{ml}$ of aforementioned three-acid mixture and then heated at $80^{\circ} \mathrm{C}$ till the solution became transparent then the solution was cooled, filtered (with whatman filter paper No.41) and diluted to $50 \mathrm{ml}$ using double distilled water [12]. The samples were analyzed for $\mathrm{Cu}, \mathrm{Cr}$ and $\mathrm{Pb}$ by using atomic absorption spectrophotometry (AAS) (Analytikjena, ZEEnit700P, Germany) method.

\section{Results}

The standard conditions for AAS (Atomic Absorption Spectrophotometer) are shown in TABLE 2. From the curves (Fig. 1,2,3) it can be said that, there was a good linear relationship between concentration of heavy metals and absorbance.

Three metals viz. $\mathrm{Pb}, \mathrm{Cr}$ and $\mathrm{Cu}$ were found in most of the sample collected from different industrial areas in Chittagong. TABLE 4, 5 and 6 present the values of heavy metals found in different samples. In the case of Nasirabad industrial area, values of $\mathrm{Cu}$ was higher than $\mathrm{Cr}$ and $\mathrm{Pb}$ for all sample. The range of $\mathrm{Cu}$ found in vegetables was 1.89 to $25.04 \mathrm{mg} / \mathrm{kg}$ where for $\mathrm{Cr}$ it was 0.63 to $2.96 \mathrm{mg} / \mathrm{kg}$ and 0.67 to $2.99 \mathrm{mg} / \mathrm{kg}$ for Pb. Arum leaves accumulate highest amount of $\mathrm{Cu}(25.04 \mathrm{mg} / \mathrm{kg})$ than others. The highest value of $\mathrm{Cr}(2.96 \mathrm{mg} / \mathrm{kg})$ found in water spinach while $2.99 \mathrm{mg} / \mathrm{kg}$ of Pb in jute leaves. The lowest value of $\mathrm{Cu}(1.89 \mathrm{mg} / \mathrm{kg}), \mathrm{Pb}(0.67 \mathrm{mg} / \mathrm{kg})$ was obtained in wax gourd and $\mathrm{Cr}(0.63 \mathrm{mg} / \mathrm{kg})$ in sweet gourd. The heavy metals found in most of the sample exceed the safe limit for $\mathrm{Pb}$ and below safe limit for $\mathrm{Cu}$ and $\mathrm{Cr}$.

Sample collected from the Agrabad industrial area gathered highest amount of $\mathrm{Cu}$ than $\mathrm{Cr}$ and $\mathrm{Pb}$. In this case, highest amount of heavy metals were came across in leafy vegetables than gourd vegetables for all sample. Jute leaves absorb maximum amount of heavy metal like $1.96,8.5$ and $2.94 \mathrm{mg} / \mathrm{kg}$ of $\mathrm{Cr}, \mathrm{Cu}$ and $\mathrm{Pb}$ respectively.

In Vatiary region, peak value of $\mathrm{Cr}(1.53 \mathrm{mg} / \mathrm{kg})$ and $\mathrm{Pb}(1.74 \mathrm{mg} / \mathrm{kg})$ was got in water spinach and $\mathrm{Cu}$ $(96.35 \mathrm{mg} / \mathrm{kg})$ in arum leaves. The minimum values were attained in wax gourd $(0.86 \mathrm{mg} / \mathrm{kg}$ of Cr$)$, bottle gourd $(\mathrm{ND}$ for $\mathrm{Cu})$ and bottle gourd $(0.99 \mathrm{mg} / \mathrm{kg}$ of $\mathrm{Pb})$. The values of $\mathrm{Cr}$ and $\mathrm{Cu}$ were below safe limit while exceed the safe limit for $\mathrm{Pb}$.

The ranges of heavy metal attained 0.22 to $4.25 \mathrm{mg} / \mathrm{kg}, 3.38$ to $6.19 \mathrm{mg} / \mathrm{kg}$ and 0.08 to $2.67 \mathrm{mg} / \mathrm{kg}$ for $\mathrm{Cr}, \mathrm{Cu}$ and $\mathrm{Pb}$ respectively for Chalkbazar region.

Fig. 4, 5, 6 demonstrate the comparison of heavy metals absorbed by vegetable with the permissible level of metals in vegetable shown in TABLE 3 [13].

Table 1: Vegetables sampled from different industrial areas

\begin{tabular}{|l|l|l|l|}
\hline English name & Local name & Scientific name & Edible part \\
\hline Jute leaves & Paat shak & Corchorus capsularis & Leaf \\
\hline Water Spinach & Kolmi shak & Ipomoea aquatica & Leaf \\
\hline Green arum leaves & Kochu shak & Colocasia esculenta & Leaf \\
\hline Sweet gourd & Misti kumda & Cucurbita maxima & Fruit \\
\hline Bottle gourd & Lau & Benincasa hispida & Fruit \\
\hline Wax gourd & Chal kumda & Fruit \\
\hline
\end{tabular}

Table 2: Standard conditions for AAS (Atomic Absorption Spectrophotometer) [14]

\begin{tabular}{|l|l|}
\hline Elements & Wavelength $(\mathbf{n m})$ \\
\hline Lead $(\mathrm{Pb})$ & 283.3 \\
\hline Chromium $(\mathrm{Cr})$ & 357.9 \\
\hline Copper $(\mathrm{Cu})$ & 324.8 \\
\hline
\end{tabular}

Table 3: Maximum safe limits of heavy metals in vegetable

\begin{tabular}{|l|l|}
\hline Metals & Values $(\mathbf{m g} / \mathbf{k g}$ dry weight) \\
\hline Copper $(\mathrm{Cu})$ & 30 \\
\hline Chromium $(\mathrm{Cr})$ & 2.3 \\
\hline
\end{tabular}




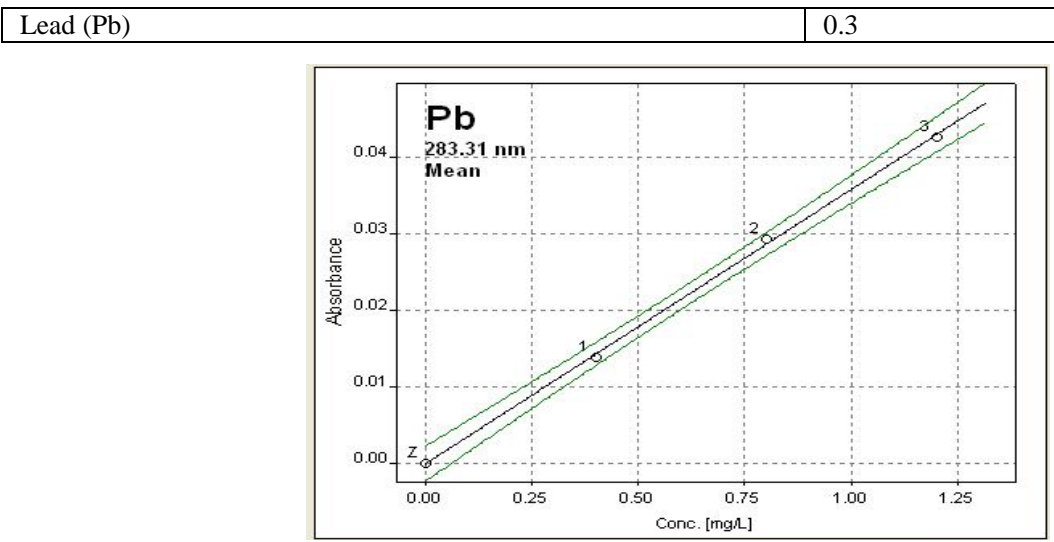

Figure 1: Calibration curve for Lead $(\mathrm{Pb})$

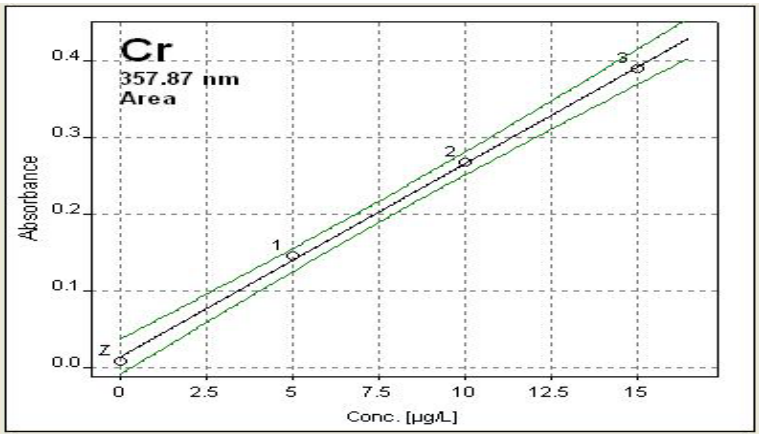

Figure 2: Calibration curve for Chromium (Cr)

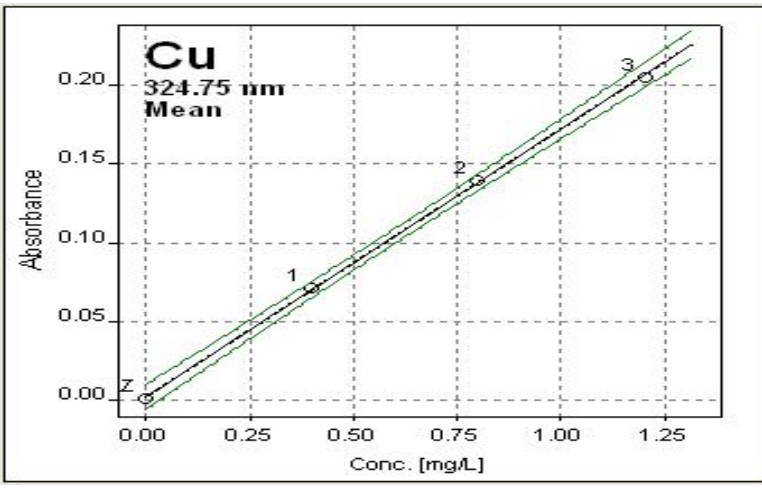

Figure 3: Calibration curve for Copper $(\mathrm{Cu})$

Table 4: Heavy metal concentration ( $\mathrm{mg} / \mathrm{kg}$ dry weight) in vegetables collected from Nasirabad Industrial Area, Chittagong, Bangladesh

\begin{tabular}{|l|l|l|l|}
\hline Vegetables & $\mathbf{C r}$ & $\mathbf{C u}$ & $\mathbf{P b}$ \\
\hline Jute leaves & $2.48 \pm 0.0015$ & $6.7 \pm 0.005$ & $2.99 \pm 0.002$ \\
\hline Water Spinach & $2.96 \pm 0.0007$ & $13.4 \pm 0.103$ & $2.28 \pm 0.003$ \\
\hline Green arum leaves & $1.12 \pm 0.0011$ & $25.04 \pm 0.079$ & $1.48 \pm 0.006$ \\
\hline Sweet gourd & $0.63 \pm 0.0006$ & $3.51 \pm 0.105$ & $0.79 \pm 0.023$ \\
\hline Bottle gourd & $0.83 \pm 0.012$ & $4.73 \pm 0.003$ & $1.06 \pm 0.017$ \\
\hline Wax gourd & $1.54 \pm 0.009$ & $1.89 \pm 0.038$ & $0.67 \pm 0.021$ \\
\hline
\end{tabular}

Table 5: Heavy metal concentration ( $\mathrm{mg} / \mathrm{kg}$ dry weight) in vegetables collected from Agrabad Industrial Area, Chittagong, Bangladesh

\begin{tabular}{|l|l|l|l|}
\hline Vegetables & $\mathbf{C r}$ & $\mathbf{C u}$ & Pb \\
\hline Jute leaves & $1.96 \pm 0.012$ & $8.50 \pm 0.009$ & $2.94 \pm 0.006$ \\
\hline Water Spinach & $1.35 \pm 0.002$ & $2.35 \pm 0.007$ & $0.17 \pm 0.018$ \\
\hline Green arum leaves & $0.78 \pm 0.001$ & $6.10 \pm 0.012$ & $1.58 \pm 0.009$ \\
\hline Sweet gourd & $0.273 \pm 0.42$ & $1.74 \pm 0.142$ & ND \\
\hline Bottle gourd & $1.23 \pm 0.128$ & ND \\
\hline \multicolumn{2}{|r|}{ Www.iosrjournals.org } \\
\hline
\end{tabular}


Detection Of Heavy Metals In Vegetables Cultivated In Different Locations In Chittagong...

\begin{tabular}{l}
\hline Wax gourd \\
ND means Not Detected
\end{tabular}
Table 6: Heavy metal concentration (mg/kg dry weight) in collected from Vatiary Industrial Area,
\begin{tabular}{|l|l|l|l|}
\hline \multicolumn{1}{|c|}{ Chittagong, Bangladesh } & $3.51 \pm 0.019$ & ND \\
\hline Vegetables & Cr & Cu & Pb \\
\hline Jute leaves & $1.36 \pm 0.003$ & $4.59 \pm 0.014$ & $1.36 \pm 0.001$ \\
\hline Water Spinach & $1.53 \pm 0.056$ & $3.895 \pm 0.006$ & $1.74 \pm 0.014$ \\
\hline Green arum leaves & $1.38 \pm 0.029$ & $6.35 \pm 0.015$ & $1.35 \pm 0.010$ \\
\hline Sweet gourd & $0.98 \pm 0.054$ & $2.96 \pm 0.004$ & $1.14 \pm 0.003$ \\
\hline Bottle gourd & ND & $0.99 \pm 0.005$ \\
\hline Wax gourd & $1.03 \pm 0.001$ & $1.56 \pm 0.003$ & $1.02 \pm 0.002$ \\
\hline
\end{tabular}

ND means Not Detected

Table 7: Heavy metal concentration ( $\mathrm{mg} / \mathrm{kg}$ dry weight) in vegetables collected from in Chalkbazar Industrial Area, Chittagong, Bangladesh

\begin{tabular}{|l|l|l|l|}
\hline Vegetables & $\mathbf{C r}$ & $\mathbf{C u}$ & $\mathbf{P b}$ \\
\hline Jute leaves & $4.25 \pm 0.012$ & $5.82 \pm 0.004$ & $2.67 \pm 0.002$ \\
\hline Water Spinach & $3.21 \pm 0.023$ & $5.94 \pm 0.010$ & $0.73 \pm 0.009$ \\
\hline Green arum leaves & $1.41 \pm 0.034$ & $4.42 \pm 0.003$ & $1.28 \pm 0.007$ \\
\hline Sweet gourd & $1.20 \pm 0.005$ & $6.19 \pm 0.004$ & $0.08 \pm 0.043$ \\
\hline Bottle gourd & $0.22 \pm 0.008$ & $5.82 \pm 0.002$ & $1.16 \pm 0.001$ \\
\hline Wax gourd & $2.44 \pm 0.002$ & $3.38 \pm 0.003$ & $0.96 \pm 0.002$ \\
\hline
\end{tabular}

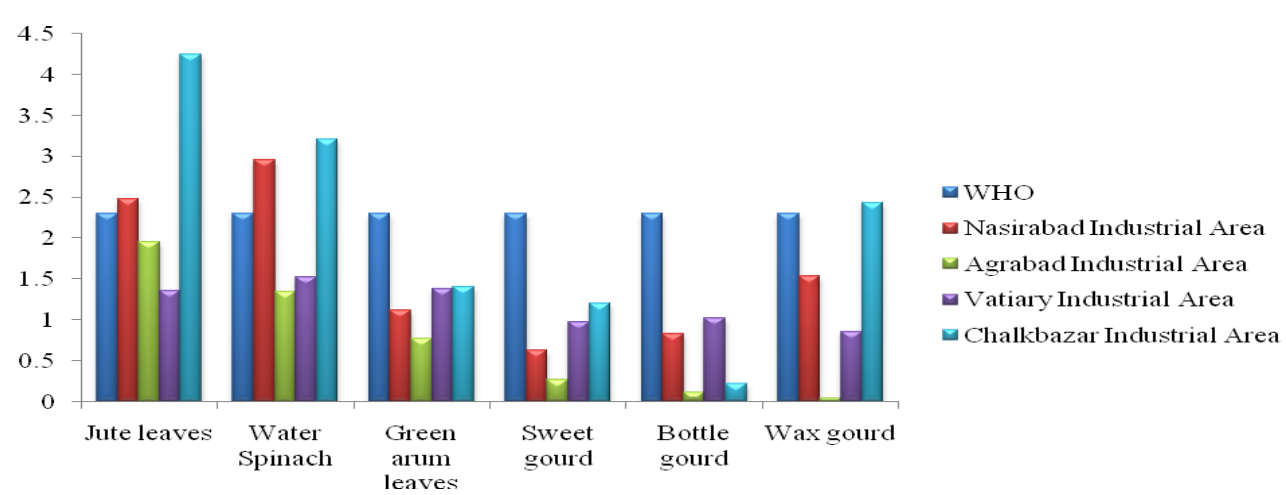

Figure 4: Distribution of $\mathrm{Cr}$ in vegetable

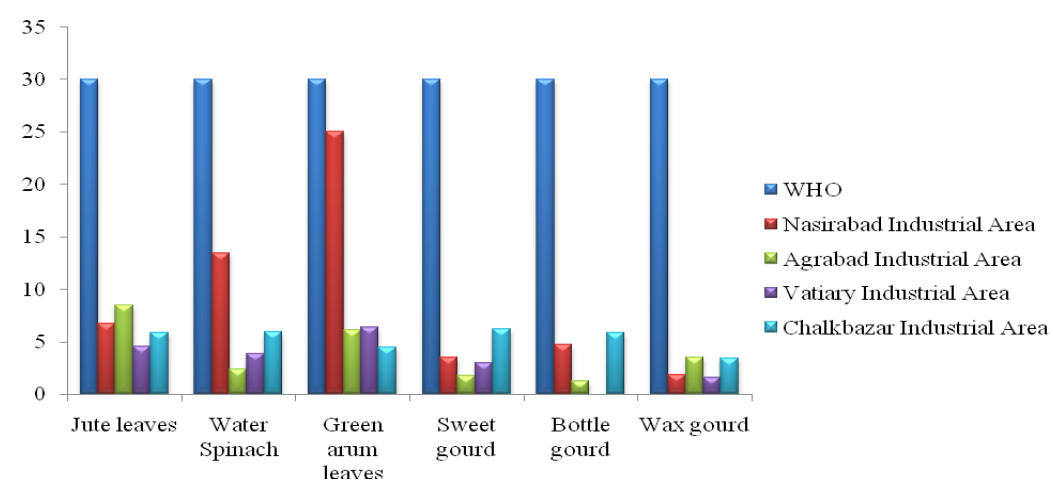

Figure 5: Distribution of $\mathrm{Cu}$ in vegetable

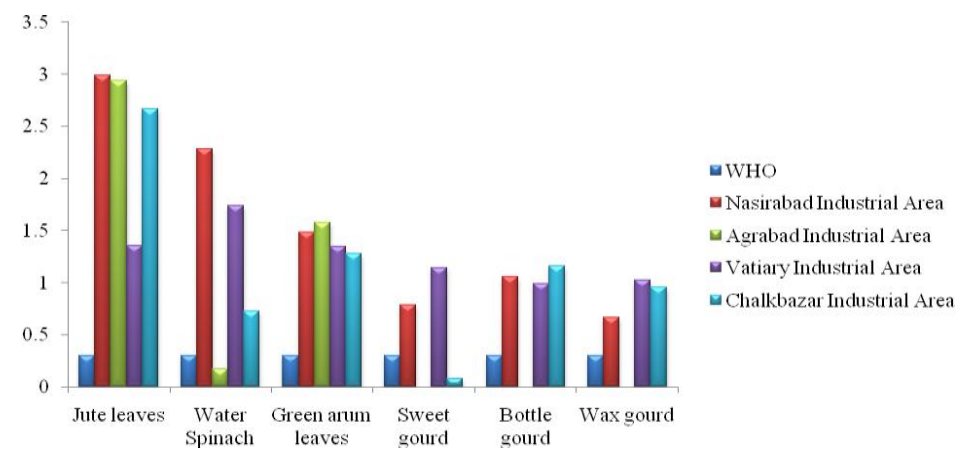




\section{Figure 6: Distribution of $\mathrm{Pb}$ in vegetable}

\section{Discussions}

Our study revealed that all samples had the copper $(\mathrm{Cu})$ concentration below the safe limit. $\mathrm{Cu}$ concentration was within permissible limit in sample collected from industrial area [15] [16]. Cu concentration (22.19-76.50mg kg-1) was found higher in leafy vegetables comparing with non-leafy vegetables in Turkey due to richness of chlorophyll [17]. There was no significant difference in metal concentration in leafy vegetables including spinach (palak) and coriander from industrial areas [18]. The concentration of $\mathrm{Cu}(2.25-5.42 \mathrm{mg} \mathrm{kg}-1)$ in vegetables grown in waste water areas of Varanasi, India was within safe limit [19].

We found excess amount of $\mathrm{Pb}$ in most of the sample collected from different industrial areas. The concentration of $\mathrm{Pb}$ was much higher in leafy vegetables compared to gourd vegetables which exceed the safe limit. Leafy vegetables had high lead concentration $(3.0-10.7 \mathrm{mg} / \mathrm{kg}-1)$ which poses health risk to human beings [17]. Due to large number of small scale industries, vehicular emissions, re-suspended road dust and diesel generator sets $\mathrm{Pb}$ may be accumulated largely [20]. Uptake of lead in plants is stimulated by $\mathrm{pH}$, particle size and Cation exchange capacity of soil as well as by root exudation and other physio-chemical parameters [21]. On the other hand, jute leaves and water spinach got too much higher concentration of $\mathrm{Cr}$ collected from Chalkbazar industrial area although arum leaves had the normal concentration and in some sample $\mathrm{Cr}$ was not detected also. Up to $200 \mu \mathrm{g} / \mathrm{day}$ of $\mathrm{Cr}$ is essential for human beings and animals to metabolize carbohydrates and lipid. Exceeding normal limit, leads creates toxicity which can result in hepatitis, gastritis, ulcers and lung cancer [22]. Cr in water leaf, garden egg leaf and bitter leaf significantly exceeded the WHO-ML (0.05 $\mathrm{mg} \mathrm{kg}$ 1) even though its PI in the soil was <1 [23]. Consequences of excess amount of consumption of $\mathrm{Cr}$ include kidney and liver damage, skin rashes, stomach upset and ulcer, respiratory problems and lung cancer and alteration of genetic materials.

\section{Conclusion}

Due to improper management of industrial waste water and effluent, it comes to the contact of soil near the industrial area. As soil absorbs the waste water, plants also can accumulate this heavy metal from waste water and may consequence an adverse health effect on human being after consumption of that vegetable. The present study reveals higher amount of $\mathrm{Pb}$ was found in vegetables collected from different industrial areas especially from Nasirabad region. The present investigation shows, among all the samples the leafy vegetables can accumulate higher amount of heavy metals compared to non leafy vegetables. Though the concentration of $\mathrm{Cu}$ was below safe limit according to the guideline of WHO, but $\mathrm{Cr}$ exceeds the limits for most of leafy vegetable and some gourd sample for the area of Chalkbazar and Nasirabad as well. So the authors suggest, not consuming too much vegetable from those region especially leafy vegetables as possible. As heavy metals have long term lethal effect on human being and animal, so it is recommended that periodic survey should be done on all food committees to protect the health of end user.

\section{Acknowledgements}

The research was supported with the help of Bangladesh University Grant Commission, Agargaon, Dhaka-1207 for providing funds and Chittagong Veterinary and Animal Sciences University, Chittagong, Bangladesh.

\section{References}

[1]. B.C. Sharma, A.K. Mishra, K.G. Bhattacharya, Metal in drinking water in a predominantly rural area, Indian journal of environmental protection, 21(4), 2000, 315-322.

[2]. Q. Yang, Ya. Xu, S. Liu, J.F. He, F. Long, Concentration and potential health risk of heavy metals in market vegetables in Chongqing, China, Ecotoxicology and environmental safety, 74, 2011, 1664-1669.

[3]. N. Gupta, D.K. Khan and S.C. Santra, An assessment of heavy metal contamination in vegetables grown in wastewater-irrigated areas of Titagarh, West Bengal, India, Bulletin of environmental contamination and toxicology, 80, 2008, $115-118$.

[4]. M. Sanchez, Cuases and effects of heavy metal pollution (Nova Science Publishers, Inc, 2008)

[5]. C.H. Luo, C.H. Liuc , B.Y. Wang, X. Liub , F. LIC, G. Zhangb and X. Lia, Heavy metal contamination in soils and vegetables near an e-waste processing site, south China, Journal of Hazardous Materials, 186, 2011, 481-490.

[6]. G.G. Yebpella, A.M. Magomya, U.U. Udiba, I. Gandu, S.M. Amana, V.C. Ugboaja and N.L. Usman, Assessment of Cd, Cu, Mn and $\mathrm{Zn}$ levels in soil, water and vegetable grown in irrigated farm along river Kubani, Zaria, Nigeria, Journal of Applied Environmental and Biological Science, 1(5), 2011, 84-89.

[7]. L.C. Chien, T.C. Hung, K.Y. Choang, C.Y. Yeh, P.J. Meng, M.J. Shieh and B.C. Han, Daily intake of TBT, Cu, Zn, Cd and As for fishermen in Taiwan. Science of the total environment, 285, 2002, 177-185.

[8]. G. R. Jansen, P.A. Kandall and C. M. Jansen, Diet evaluation, a guide to planning a healthy diet. New York: Academic Press, 1990, 279.

[9]. S. Sinha, G. Sinam, K. Mishra, S. Mallick, Metal accumulation, growth, antioxidants and oil yield of Brassica juncea L. exposed to different metals, Ecotoxicology and environmental safety, 73(6), 2010, 1352 - 1361. 
[10]. M. A. Radwan, A.K. Salama, Market basket survey for some heavy metals in Egyptian fruits and vegetables, Journal of food chemistry and toxicology, 44 (22), 2006, 1273- 1278.

[11]. H.L. Ramesh and V.N. Yogananda Murthy, Assessment of heavy metal contamination in green leafy vegetables grown in Bangalore urban district of Karnataka, Advances in life science and technology, 6, 2012, 40-51.

[12]. A. Jafarian and M. Alehashem, Heavy metal contamination of vegetables in Isfahan, Iran, Research in pharmaceutical sciences, $8(1), 2013,51-58$.

[13]. Codex Alimentarius Commission [FAO/WHO], Food additives and contaminants, Joint FAO/WHO Food Standards Program, ALINORM 01/12A, 2001, 1-289.

[14]. MMAF (Manual of methods of analysis of food-metals), Directorate general of health services, Ministry of Health and Family Welfare, Government of India, new Delhi, 2005.

[15]. M. Arora, B. Kiran, S. Rani, A. Rani, B. Kaur and N. Mittal, Heavy metal accumulation in vegetables irrigated with water from different sources, Food chemistry, 111, 2008, 811-815.

[16]. B. Debopam, B. Himadri, M. Sibabrata, P. Anju, B. Debabrata and R. Lalitagauri, Heavy metal contamination in fruits and vegetables in two districts of West Bengal, India. Electronic journal of environmental, agricultural and food chemistry, 9(9), 2010, 1423-1432.

[17]. D. Demirezen and A. Ahmet, Heavy metal levels in vegetables in Turkey are within safe limits for Cu, $\mathrm{Zn}, \mathrm{Ni}$ and exceeded for Cd and $\mathrm{Pb}$, Journal of food quality, 29, 2006, 252-265.

[18]. K. Fytianos, K. Ktasianis, P. Tziantafyllox and G. Zacchariadis, Accumulation of heavy metals in vegetables grown in an industrial area in relation to soil, Bulletin of environmental contamination and toxicology, 67, 2011, 423-443.

[19]. R.K. Sharma, M. Agarawal and F.M. Marshall, Heavy metal contamination in vegetables grown in waste water irrigated areas of Varanasi, India, Bulletin of environmental contamination and toxicology, 77, 2006, 311-318.

[20]. M.S. Al Jassir, A. Sarkar and M.A. Khaliq, Deposition of heavy metal on green leafy vegetables sold on roadsides of Riyadh city, Saudi Arabia, Journal of environmental contamination and toxicology, 75, 2005, 1020-1027.

[21]. H. Lokeshwari and G.T. Chandrappa, Impact of heavy metal contamination of Bellandur lake on soil and cultivated vegetation, Current Science, 91(5), 2006, 622-627.

[22]. E.C. Garcia, M.L. Cabrera, Lorenzo, J. Sanchez and C. Lopez, Daily dietary intake of chromium in Southern Spain measured with duplicate diet sampling, British journal of nutrition, 86, 2001, 391-396.

[23]. J.O. Oti Wilberforce and Nwabue, Heavy metals effect due to contamination of vegetables from Enyigba Lead Mine in Ebonyi State, Nigeria, Canadian Center of Science and Education, Environment and Pollution, 2 (1), 2013,1927-0917. 